\title{
Child psychomotor development and its relationship with socio-demographic and family stimulation factors in children from Bariloche, Argentina
}

\author{
Gilda Garibotti, Ph.D. in Statistics, ${ }^{a}$ Haydeé Comar, M.D.,${ }^{a, c}$ Cecilia Vasconi, B.S. in \\ Social Work, ${ }^{b}$ Gabriela Giannini, M.D., ${ }^{c}$ and Claudia Pittau, M.D. ${ }^{c}$
}

\begin{abstract}
Introduction. This study analyzed the association between psychomotor development and sociodemographic and family stimulation factors in 3-year-old children from San Carlos de Bariloche. Population and Methods. A total of 152 apparently healthy children aged 35-37 months old who attended municipal and private kindergartens were evaluated. Children's performance in personal-social, fine motor, language and gross motor skills development using the National Screening Test was analyzed. The relationship between environmental factors and the achievement of developmental milestones was studied using a multivariate logistic regression model.

Results. Twenty seven percent of children did not pass the test. The most common outcome measures associated with altered developmental milestones were no reading, low birth weight, and the parents' lower education level. The association with reading was always positive; and this also occurred in relation to the parents' education level. A low birth weight had a negative association with the possibility of passing four milestones, three of which were gross motor skills. Children who attended municipal kindergartens had a low performance in three language milestones, one personal-social milestone and one fine motor milestone when compared to national profiles.

Conclusions. The percentage of children who did not pass the test was $27 \%$. The most common outcome measures associated with altered developmental milestones were lack of reading to the child, low birth weight, and the parents' lower education level.

Key words: child development, psychomotor performance, family stimulation.
\end{abstract}

http:/ /dx.doi.org/10.5546/aap.2013.384

\section{INTRODUCTION}

An adequate mental and physical health status during pre-school age is critical for children to start school ready to learn, ${ }^{1,2}$ especially considering that the health and the academic performance of children have a major effect on their future achievements. $^{3}$
Genetic factors, nutrition, health, environment where children grow, and opportunities offered by their families are all determinants of child development. ${ }^{4,5}$ A family environment that promotes learning favors a comprehensive development. ${ }^{6-9}$ Regardless of the skills that a child could have to achieve high competence levels, a poor environment can negatively affect the materialization of such skills. ${ }^{4}$

In many cases, detecting developmental delays and investigating their causes allow to implement treatments and support measures that could favor the child's development. ${ }^{10-12}$ Several studies show evidence on the benefits of an early intervention in relation to the patient's progress in the short- and medium-term. ${ }^{13-15}$ As children grow, the influence of their environment also increases, and the differences in psychomotor development among children with different stimulation levels become deeper.

The objective of this study was to analyze the relationship between psychomotor development and sociodemographic and family stimulation factors in a population of 3-yearold children who attend different kindergartens in the city of Bariloche.

This study is part of a large project that plans to assess the psychomotor development of the same children at 5 years old, which will enable to perform a comparative analysis to check if environmental factors have greater influence over time. This is the first study of this kind in the region. 


\section{POPULATION AND METHODS}

This study was conducted on a sample of apparently healthy children aged 3 years \pm 1 month old who attend initial education facilities in the city of Bariloche. All eight municipal kindergartens (MKs) and five private kindergartens (PKs) participated. Children attending MKs usually come from low-income families. Since the study objective was to analyze the association between development and sociodemographic factors, the selected PKs were among the seven facilities that serve the highestincome families. Participants were selected on a monthly basis. Based on the lists provided by each type of institution, children with the age in the range of interest at least 15 days of each month were identified. Out of them, 5 children were randomly selected to be interviewed, with a total of 10 children each month. If any of them was unable to attend the interview, another child was randomly selected. Parents were invited to participate, information was provided on the project and they were asked to give their consent.

The interview entailed recording information on socio-demographic aspects and family stimulation characteristics, and assessing the child's performance of developmental milestones. The interviews were conducted by the pediatricians who co-wrote this article, between June 2010 and May 2012, with interruptions only during summer vacations. Interviews were conducted at the kindergarten in the presence of the child and one of his/her parents.

For the assessment of development, ${ }^{25}$ fine and gross motor skills, personal-social, and language milestones were applied using the National Screening Test (Prueba Nacional de Pesquisa, PRUNAPE by its acronyn in spanish ) for children aged 35-37 months old. ${ }^{16}$ Milestone assessments were implemented by trained personnel and in accordance with the instructions of the PRUNAPE Technical Brochure. ${ }^{16}$ Categories included in the developmental milestones were yes: if the child passed, and no: if the child did not pass the milestone or refused to perform.

If the child did not pass the PRUNAPE, he/ she was referred to his/her pediatrician with indications on the need to be assessed for possible developmental disorders and emphasizing the significance of follow-up. The principals of the kindergartens were reported on the development areas where children showed most difficulties.

The statistical analysis included, first of all, a calculation of the confidence intervals (CI) of the percentage of children who passed each developmental milestone in relation to the total number of children and the groups attending MKs and PKs separately. Using the $\chi^{2}$ test, the percentage of children who passed each test was compared based on whether they attended a MK or a PK.

The relationship between biological, sociodemographic, and family stimulation risk factors and the achievement of developmental milestones was studied using a multivariate logistic regression model. Biological and sociodemographic outcome measures included: sex, preterm birth, low birth weight (category 1: $\leq 2500 \mathrm{~g}$; 2: $>2500 \mathrm{~g}$ ), adolescent pregnancy (if the mother had the child before turning 19 years old), maximum education level attained by the parents (category 1: no education or primary education; 2: secondary, tertiary, or university education), parents employment modality (category 1: permanent; 2: temporary or day laborer, 3: no employment), and type of institution where the child attended (category 1: municipal; 2: private). An index was prepared combining the data on whether the family received a child benefit (yes/no) and whether they had health coverage through a social insurance program or a managed care organization (yes/no), with category 1: two "yes" answers; 2: one "yes"; 3: two "no" answers.

Family stimulation was evaluated using a survey based on the HOME inventory, ${ }_{1}^{17}$ leaving out the direct observation of the child in his/ her home. The following aspects related with the child's comprehensive development were assessed. ${ }^{7,18,19-21}$ Learning stimulation materials: questions were asked about whether the child had three or more children's books, a ball, a tricycle or bicycle, color pencils, puzzles, building blocks, dolls or action figures, and toy cars. Category 1: less than 6 of these elements; 2: 6 or more of these elements. Academic stimulation: whether the child was taught animal names, colors, how to count, and the names of letters, and whether he/she listened to children's music. Category 1: less than 4 of these activities; 2: 4 or more of these activities. Modeling and stimulation of social maturity, which comprise the following aspects: whether the child is requested to respect meal times, go to bed before 9 PM, wash his/ her teeth at least once a day, and wash his/her hands before meals and after using the bathroom. Category 1: less than 3 of these activities; 2: 3 or more of these activities. Varied experiences: whether the child went out at least once in the 
previous week, visited or was visited by family or friends in the previous month, watches less than one hour of television a day, went on vacations at least once in the previous year. Category 1 : less than 3 of these activities; 2: 3 or more of these activities. Reading: whether stories are read to the child. Category 1: no reading in the previous week; 2 : reading at least once in the previous week.

The adequate model for each milestone was selected based on the forward stepwise selection method using the Akaike Information Criterion. ${ }^{22}$

Statistical analysis were done using the $\mathrm{R}$ statistical package, version 2.15.1.23.

\section{RESULTS}

A total of 152 children were interviewed, $53 \%$ from municipal kindergartens and $47 \%$ from private kindergartens. Of them, $7 \%$ of the families from MKs and 16\% of the families from PKs refused to participate. Socio-demographic characteristics of the families are described in Table 1.

Families of low socio-economic and education levels were more predominant in municipal institutions.
In relation to child development, Table 2 shows the $95 \%$ CIs for the percentage of children who passed each milestone, for all children, and for the MK and PK groups; the $\mathrm{p}$ value of the comparison between the percentage of children attending MKs and PKs who passed the tests; and the percentile values and the age at which the child is expected to achieve the milestone at a national level. ${ }^{24}$

Most differences between children from MKs and PKs were found in the language milestone group; six out of eight had significant differences: "saying phrases (noun, verb)", "humming in front of others", "saying full phrases", "making opposite analogies", "understanding prepositions", and "complying with two consecutive indications". In all cases, the CIs of the PKs tended more to the right than those of MKs. Tests referring to "saying full name", "making opposite analogies", and "complying with two consecutive indications" were passed by a lower percentage of children from MKs when compared to the milestone at a national level. The milestone "making opposite analogies" was the only one attained by a lower percentage of children from PKs than that recorded at a national level.

TABLE 1. Social characteristics of studied families

\begin{tabular}{|c|c|c|c|}
\hline & \multicolumn{2}{|c|}{ Type of kindergarten } & \multirow[b]{2}{*}{$p$} \\
\hline & Municipal & Private & \\
\hline Maximum education level attained by the father & & & $<0.001$ \\
\hline No education or primary education & 64.5 & 8.5 & \\
\hline Secondary education & 30.3 & 31 & \\
\hline Tertiary or university education & 5.3 & 60.6 & \\
\hline Maximum education level attained by the mother & & & $<0.0001$ \\
\hline No education or primary education & 57.5 & 7 & \\
\hline Secondary education & 36.2 & 21.1 & \\
\hline Tertiary or university education & 6.2 & 71.8 & \\
\hline Father's employment modality & & & 0.0002 \\
\hline Permanent & 64.9 & 93 & \\
\hline Temporary or day laborer & 29.9 & 7 & \\
\hline Unemployed & 5.2 & 0 & \\
\hline Mother's employment modality & & & 0.0015 \\
\hline Permanent & 49.4 & 77.5 & \\
\hline Temporary or day laborer & 13.9 & 8.5 & \\
\hline Unemployed & 36.7 & 14.1 & \\
\hline
\end{tabular}

Percent distribution of the social characteristics of the studied families by type of kindergarten and $\mathrm{p}$ value of the comparison. 
A significant difference was found between MKs and PKs in terms of the gross motor skill milestones "jumping on both feet" and "making wide jumps." The percentage of children who passed the test for "jumping on both feet" (95\% CI: 68-87) was lower than the one recorded at a national level, with a $90 \%$ percentile at 34 months old.

The percentage of children who failed the PRUNAPE was 27\% (95\% CI: 20-35); and the difference between MKs (31\%) and PKs (24\%) was not significant.

Results of the assessment of the association between psychomotor development and biological, socio-demographic, and family stimulation factors are shown in Table 3. No significant association was found between the following outcome measures and developmental milestones: adolescent pregnancy, employment modality of the father and mother, child benefit and health coverage index, academic stimulation, and modeling and stimulation of social maturity. Children whose mothers had completed secondary, tertiary or university education had 3.7 more chances of passing the "matching colors" milestone than those whose mothers had only attained a primary education level.

Outcome measures most commonly associated

TABLE 2. Psychomotor development and type of kindergarten

\begin{tabular}{|c|c|c|c|c|c|}
\hline \multirow[b]{2}{*}{ Milestones } & \multirow[b]{2}{*}{ Total } & \multicolumn{2}{|c|}{ Type of kindergarten } & \multirow[b]{2}{*}{$p$} & \multirow[b]{2}{*}{ PRUNAPE percentile } \\
\hline & & Municipal & Private & & \\
\hline \multicolumn{6}{|l|}{ Personal-social skills } \\
\hline Responding to the observer's call & 87.96 & 84.97 & 84.98 & 1 & $90=28 \mathrm{~m}$ \\
\hline Sphincter control during the day & 90.98 & 89.99 & 85.98 & 0.6052 & $90=33 \mathrm{~m}$ \\
\hline Removing clothes or shoes & 86.96 & 79.95 & 88.99 & 0.1888 & $90=34 \mathrm{~m}$ \\
\hline Putting on clothes or shoes & 92.99 & 93.100 & 86.98 & 0.3096 & $90=36 \mathrm{~m}$ \\
\hline Putting puzzles together & 78.90 & 70.88 & 81.96 & 0.1326 & $75=33 \mathrm{~m}$ \\
\hline Matching colors & 37.54 & 25.48 & 43.68 & $0.0246^{*}$ & $50=35 \mathrm{~m}$ \\
\hline \multicolumn{6}{|l|}{ Fine motor skills } \\
\hline Scribbling & 94.100 & 91.100 & 93.100 & 1 & $90=19 \mathrm{~m}$ \\
\hline Dumping a raisin into a bottle & 94.100 & 91.100 & 93.100 & 1 & $90=19 \mathrm{~m}$ \\
\hline Building a 4 cube tower & 92.99 & 91.100 & 88.99 & 0.9046 & $90=24 \mathrm{~m}$ \\
\hline Building an 8 cube tower & 78.90 & 74.91 & 76.93 & 0.858 & $75=31 \mathrm{~m}$ \\
\hline Building a bridge & 55.71 & 47.69 & 57.80 & 0.2072 & $50=31 \mathrm{~m}$ \\
\hline Correcting tower & 60.76 & 50.72 & 64.85 & 0.0759 & $50=27 \mathrm{~m}$ \\
\hline \multicolumn{6}{|l|}{ Language skills } \\
\hline Naming two figures & 88.97 & 84.97 & 86.98 & 0.8605 & $90=29 \mathrm{~m}$ \\
\hline Saying phrases (noun and verb) & 90.98 & 81.96 & 95.100 & $0.0167^{*}$ & $90=29 \mathrm{~m}$ \\
\hline Humming in front of others & 87.96 & 77.93 & 93.100 & $0.0117^{*}$ & $90=34 \mathrm{~m}$ \\
\hline Saying full phrases & 78.90 & 65.85 & 86.98 & $0.0037^{* *}$ & $75=32 \mathrm{~m}$ \\
\hline Saying full name & 53.69 & 47.69 & 52.75 & 0.5857 & $75=34 \mathrm{~m}$ \\
\hline Making opposite analogies & 10.23 & 2.16 & 15.37 & $0.0104^{*}$ & $50=35 \mathrm{~m}$ \\
\hline Understanding prepositions & 46.64 & 28.52 & 59.82 & $<0.0001^{* * *}$ & $50=32 \mathrm{~m}$ \\
\hline $\begin{array}{l}\text { Complying with two } \\
\text { consecutive indications }\end{array}$ & 39.56 & 24.48 & 46.71 & $0.011^{*}$ & $50=32 \mathrm{~m}$ \\
\hline \multicolumn{6}{|l|}{ Gross motor skills } \\
\hline Kicking a ball & 87.96 & 81.96 & 88.99 & 0.2941 & $90=21 \mathrm{~m}$ \\
\hline Throwing a ball & 87.96 & 80.95 & 90.100 & 0.0936 & $90=29 \mathrm{~m}$ \\
\hline Jumping on both feet & 79.91 & 68.87 & 84.98 & $0.0252^{*}$ & $90=34 \mathrm{~m}$ \\
\hline Standing on one foot for 5 seconds & 35.52 & 35.58 & 28.52 & 0.4466 & $50=28 \mathrm{~m}$ \\
\hline Making wide jumps & 48.65 & 55.77 & 34.58 & $0.0147^{*}$ & $50=30 \mathrm{~m}$ \\
\hline
\end{tabular}

${ }^{*} \mathrm{p}<0.05,{ }^{* *} \mathrm{p}<0.01,{ }^{* * *} \mathrm{p}<0.001 .95 \%$ confidence intervals of passing result percentages per milestone: total and by type of institution. $p$ value of the comparison between the percentage of children who passed the milestones in each type of institution. Percentile and age in months (m) at which a child is expected to perform each milestone at a national level. 
with developmental milestones were reading, low birth weight, and the parent's education level. In all cases, reading and a higher education level of parents favored the likelihood of achieving the milestones. Of the interviewed children, 36\% were never read stories, $58 \%$ of them from MKs and $13 \%$ from PKs, $p<0.0001$. It is worth mentioning that reading, the mother's education level and the father's education level were factors never significantly associated together with a milestone.

The number of hours spent watching television was included in the analysis using the varied experiences outcome measure; $58 \%$ of interviewed children watched more than one hour of television a day, and 31\% did so alone.

A low birth weight was associated with a reduction in the possibility of passing three gross motor skill milestones. The fine motor skill milestones were only related to the education level of the parents.

\section{DISCUSSION}

In this study, we assessed the psychomotor development of 3-year-old children attending municipal or private kindergartens in the city of Bariloche. This is the first study of this kind in the region.

The national developmental profile was obtained based on a sample biased towards a higher education level of the mother in comparison with national values; ${ }^{25}$ therefore, it can be considered a desirable goal for all Argentine children. Comparing our results with national ones, the percentage of children who failed the PRUNAPE was similar. ${ }^{26}$ However, children from municipal institutions had a low performance in three language milestones, one personal-social milestone, and one fine motor skill milestone when compared to national profiles. PK children showed a low performance only in relation to "making opposite analogies". The

TABLE 3. Association between biological, socio-demographic and family stimulation factors and the capability to pass developmental milestones

\begin{tabular}{|c|c|c|c|c|c|c|c|c|c|}
\hline Milestones & $\begin{array}{l}\text { Learning } \\
\text { material }\end{array}$ & $\begin{array}{c}\text { Varied } \\
\text { experiences }\end{array}$ & Reading & $\begin{array}{c}\text { Type of } \\
\text { institution }\end{array}$ & $\begin{array}{l}\text { Education of } \\
\text { the mother }\end{array}$ & $\begin{array}{l}\text { Education } \\
\text { of the fathe }\end{array}$ & $\begin{array}{l}\text { er Gender } \\
\text { er }\end{array}$ & Preterm & $\begin{array}{l}\text { Low birth } \\
\text { weight }\end{array}$ \\
\hline $\begin{array}{l}\text { Responding to the } \\
\text { observer's call }\end{array}$ & NS & NS & $4.9^{*} \mathrm{y} / \mathrm{n}$ & NS & NS & NS & NS & NS & NS \\
\hline Removing clothes or shoe & es NS & NS & $6.7^{*} \mathrm{y} / \mathrm{n}$ & NS & NS & NS & NS & $7.2^{* *} \mathrm{y} / \mathrm{n}$ & NS \\
\hline Putting puzzles together & NS & NS & NS & NS & NS & $6.8^{* *} 2 / 1$ & NS & NS & $6.3^{*} 2 / 1$ \\
\hline Matching colors & NS & NS & NS & NS & $3.7^{* *} 2 / 1$ & NS & $2.9^{* *} \mathrm{f} / \mathrm{m}$ & NS & NS \\
\hline Building a bridge & NS & NS & NS & NS & $3.4^{* *} 2 / 1$ & NS & NS & NS & NS \\
\hline Correcting tower & NS & NS & NS & NS & NS & $3.2^{* *} 2 / 1$ & NS & NS & NS \\
\hline $\begin{array}{l}\text { Humming in front } \\
\text { of others }\end{array}$ & NS & NS & NS & $9.4^{*} 2 / 1$ & NS & NS & NS & NS & NS \\
\hline Saying full phrases & NS & $3.9 * 2 / 1$ & $3.2^{*} \mathrm{y} / \mathrm{n}$ & NS & NS & NS & $4.5^{* *} \mathrm{f} / \mathrm{m}$ & NS & NS \\
\hline Saying full name & NS & NS & NS & NS & NS & NS & NS & $3.1^{*} \mathrm{y} / \mathrm{n}$ & NS \\
\hline Understanding prepositio & ons NS & NS & NS & $4.4^{* * *} 2 / 1$ & NS & NS & NS & NS & NS \\
\hline $\begin{array}{l}\text { Complying with two } \\
\text { consecutive indications }\end{array}$ & $4.9^{* * *} 2 / 1$ & NS & NS & NS & NS & NS & NS & NS & NS \\
\hline Kicking a ball & NS & NS & $8.6^{*} \mathrm{y} / \mathrm{n}$ & NS & NS & NS & NS & NS & $8.8^{* *} 2 / 1$ \\
\hline Throwing a ball & NS & NS & $6.8^{*} \mathrm{y} / \mathrm{n}$ & NS & NS & NS & NS & NS & NS \\
\hline Jumping on both feet & NS & NS & $7.8^{* * *} \mathrm{y} / \mathrm{n}$ & NS & NS & NS & NS & NS & $4.1^{*} 2 / 1$ \\
\hline $\begin{array}{l}\text { Standing on one foot } \\
\text { for } 5 \text { seconds }\end{array}$ & NS & NS & NS & NS & NS & NS & $2 * \mathrm{f} / \mathrm{m}$ & NS & NS \\
\hline Making wide jumps & $5.9^{* * *} 2 / 1$ & NS & NS & NS & NS & NS & NS & NS & $6.1 * 2 / 1$ \\
\hline
\end{tabular}

${ }^{*} \mathrm{p}<0.05,{ }^{* *} \mathrm{p}<0.01,{ }^{* * *} \mathrm{p}<0.001$. The table shows the significant odds ratios of the multiple logistic regression model. The milestones for which it was not possible to make an adequate adjustment of the logistic regression model or had no significant association with the assessed factors were not included. y: yes, n: no, f: female, m: male; categories 1 and 2 of each outcome measure are detailed in the text.

NS: not significant. 
development of language is related to the child's cognitive skills and influences his/her academic performance. $^{27}$

Almost $60 \%$ of all interviewed children watch television for more than one hour a day, and $31 \%$ always do so alone. Several studies have demonstrated that watching television has negative effects on the children's health because the time spent in front of the TV is taken away from play time, from interaction with their parents and from reading, and because of the contents of TV shows..$^{28,29}$ Silinger, et al. ${ }^{30}$ have highlighted the importance of accompanying children while they are in front of the television so as to establish a relationship and help them develop an active and critical attitude towards what they are watching.

Reading is one of the more effective instruments to help children develop their language and, in turn, is related to the development of thinking. ${ }^{31}$ Reading to a child from an early age also improves the development of reading and writing skills.

This study has several sources of bias. Two private schools in Bariloche refused to take part. Some of the parents invited to participate declined, and others were not able to arrange a date for the interview with the pediatricians.

Several studies found a relationship between biological and environmental outcome measures and mental and physical development., ${ }^{7,32} \mathrm{~A}$ better performance was found in relation to six milestones among the children to whom stories were read. In other cases, parents education level was associated with a better achievement of developmental milestones in their children. However, no significant association was found between socio-economic indicators and developmental milestones. Recart, et al. ${ }^{19,20}$ detected that the presence of books and reading material in the house offers a significant positive association with the development of cognitive functions at a pre-school age and with school performance at 8-9 years old. These authors consider that the presence of books in the house demonstrates that parents are interested in reading. They also found that the mother's education level influences children's academic performance.

In this sense, the implementation of actions aimed at promoting interest in reading from an early age is essential. Argentina offers several reading promotion programs (Invitemos a leer, FUNDASAP; Leer es contagioso, Ministry of Social
Welfare; Leer es fundamental, Fundación Leer).

Policies that promote continuing education among youth and adults are also very important given that the parents' level of education was found to be one of the outcome measures related to child development.

Female children showed a better performance in three milestones than boys, which is consistent with other authors' findings. ${ }^{24,27}$

Several studies show evidence on the efficacy of child development intervention programs and their subsequent impact on academic performance, especially among low socio-economic level populations. ${ }^{11,13,15}$ The greatest benefit is obtained through programs that are started early and maintained in the long term. ${ }^{11,13,33-35}$

This study underscores the importance of family stimulation in child development.

The low performance in some of the tests of children attending municipal institutions should be a warning sign regarding the significance of including psychosocial development in child health assessments and the implementation of early stimulation programs. These actions will enable an early management of potential developmental disorders.

In order to ensure equal opportunities for all children, adequate resources that will improve their learning environment are necessary because a better environment during early childhood can contribute to an improved psychosocial development and will have an impact on school performance and the prevention of academic failure.

\section{CONCLUSIONS}

The percentage of children who did not pass the PRUNAPE was $27 \%$. In relation to six out of eight milestones, the percentage of children attending MKs who passed each milestone was significantly lower than that of children attending PKs, and in relation to three milestones, their performance was below that recorded at a national level. The most common outcome measures associated with altered developmental milestones were no reading, low birth weight, and the parents' lower education level.

\section{Acknowledgments}

We would like to thank the principals of all the institutions for collaborating with the study and facilitating the interviews: G. Blanco, S. Díaz, P. Fernández, V. Gerzovich, A. Gioiosa, N. Mitri, A. Panes, M. C. Sáenz, A. Vallone, and N. Zanzi. We 
would especially like to thank the families that participated in the study.

To S. Calvelo, M.D., for reviewing the manuscript and her valuable feedback. To Paola Ayalef for helping to arrange the interviews.

\section{REFERENCES}

1. Haskins R, Rouse C. Closing achievement gaps. Future Child 2005;16(1):1-7.

2. Lukin A. El rol del pediatra en el equipo de salud escolar. Arch Argent Pediatr 2002;100(3):245-9.

3. Forrest C, Riley A. Childhood origins of adult health: A basis for life-course health policy. Health Aff (Millwood) 2004;23(5):155-64.

4. Lejarraga H. La interacción entre genética y medio ambiente. En: Lejarraga H. Desarrollo del niño en contexto. Buenos Aires: Paidós; 2008. Págs.99-140.

5. Sesa S, Frassoni A, Sabulsky J, Agrelo F. Análisis longitudinal y comparativo del desarrollo infantil en la ciudad de Córdoba. Arch Argent Pediatr 2001;99(2):119-26.

6. Bustos C, Herrera M, Mathiesen M. Calidad del ambiente del hogar: inventario HOME como un instrumento de medición. Estud Pedagog 2001;27:7-22.

7. Torralva T, Cugnasco I, Manso M, Sauton F, et al. Desarrollo mental y motor en los primeros años de vida: su relación con la estimulación ambiental y el nivel socio-económico. Arch Argent Pediatr 1999;97(5):306-16.

8. Viguer P, Serra E. Nivel socioeconómico y calidad del entorno familiar en la infancia. An Psicol 1996;12(2):197205.

9. Mathiesen M, Herrera M, Merino J, Villalón M, et al. Calidad educativa familiar y desarrollo infantil del párvu lo. Paideia. Rev Educ 2001;30-31:61-79.

10. Lejarraga H, Menendez A, Menzano E, Guerra L, et al. Screening for developmental problems at primary care level: a field programme in San Isidro, Argentina. Paediatr Perinat Epidemiol 2008;22:180-7.

11. Halpern R, Figueiras A. Environmental influences on child mental health. J Pediatr 2004;80(2):S104-10.

12. Beeghly M. Translational research on early language development: Current challenges and future directions. Dev Psychopathol 2006;18(3):737-57.

13. Campbell F, Ramey C. Effects of early intervention on intellectual and academic achievement: a follow-up study of children from low-income families. Child Dev 1994;65:68498.

14. Bachmann K, Arvedson J. Early identification and intervention for children who are hearing impaired. Pediatr Rev 1998;19(5):155-65.

15. Majnemer A. Benefits of early intervention for children with developmental disabilities. Semin Pediatr Neurol 1998;5(1):62-9.

16. Lejarraga H, Kelmansky D, Pascucci M, Salamanco G. Prueba Nacional de Pesquisa PRUNAPE Buenos Aires: Edición Fundación Hospital Garrahan; 2005.

17. Bradley R, Caldwell B. The HOME inventory and family demographics. Dev Psychol 1984;20:315-20.
18. Regatky N, Lamy P, Salamanco G. Evaluación preescolar. Una experiencia en el consultorio de seguimiento longitudinal del niño y la familia. Rev Hosp Niños BAires 2008;50(227):70-8.

19. Recart M, Mathiesen M, Herrera M. Relaciones entre algunas características de la familia del preescolar y su desempeño escolar posterior. Rev Enf Educ 7(1):105-23.

20. Recart M, Mathiesen M. Calidad educativa del ambiente familiar y su relación con el desarrollo de funciones cognitivas en el preescolar. Psykhe 2003;12(2):143-51.

21. Bradley R, Caldwell B, Rock S, Ramey C, et al. Home environment and cognitive development in the first 3 years of life: A collaborative study involving six sites and three ethnic groups in North America. Dev Psychol 1989;25(2):21735.

22. Kutner M, Nachtsheim C, Neter J, Li W. Applied linear statistical models. 5th ed.: McGraw-Hill/Irwin; 2005.

23. R Core Team. R: a language and environment for statistical computig. Viena, Austria: R foundation for statistical computing; 2012. Report No.: 3-900051-07-0.

24. Lejarraga H, Pascucci M, Krupitzky S, Kelmansky D, et al. Psychomotor development in Argentinian children aged 0-5 years. Paediatr Perinat Epidemiol 2002;16(1):47-60.

25 Lejarraga H, Krupitzky S, Giménez E, Diament N, et al. The organisation of a national survey for evaluating child psychomotor development in Argentina. Paediatr Perinat Epidemiol 1997;11:359-73.

26. Pascucci M, Lejarraga H, Kelmansky D, Álvarez M, et al. Validación de la prueba nacional de pesquisa de trastornos de desarrollo psicomotor en niños menores de 6 años. Arch Argent Pediatr 2002;100(5):374-84.

27. Regatky N,Lamy P,Camarasa A, Miguez R, et al. Lenguaje infantil: una experiencia de trabajo en el Consultorio de Niño Sano del Hospital de Niños “Ricardo Gutiérrez". Rev Hosp Niños BAires 2009;51(233).

28. Bar-on M. The effects of television on child health: implications and recommendations. Arch Dis Child 2000;83:289-92.

29. Dietz W, Strasburger V. Children, adolescents, and television. Curr Probl Pediatr 1991;21:8-31.

30. Silinger E, Braga M, Busaniche J, Eymann A. ¿Qué ven nuestros niños en la televisión? Pokémon: un modelo de análisis. Arch Argent Pediatr 2001;99(5):426-35.

31. Sociedad Argentina de Pediatría. Invitemos a leer: Programa de promoción de la lectura; 2002. Report No.: 987-9051-42-4.

32. Sonnander K, Claesson M. Predictors of developmental delay at 18 months and later school achievement problems. Dev Med Child Neurol 1999;41:195-2002.

33. CESNI. Proyecto Tierra del Fuego - Encuesta de desarrollo infantil. Fundación J Macri; 1996.

34. Fernández L, Riquelme P. Sistematización programa de estimulación temprana. Chile: Universidad dela Frontera/ Universidad Católica de Temuco; 2006.

35. Barnett $W$. Long-term effects of early childhood programs on cognitive and school outcomes. Future Child 1995;5(3):2550. 